\title{
Joanna Konopczak
}

Oddział Zbiorów Muzycznych Biblioteki Uniwersyteckiej we Wrocławiu

\section{Zatrzymane w czasie. Wartość historyczna szaty graficznej dziewiętnasto- i dwudziestowiecznych druków muzycznych z kolekcji Biblioteki Uniwersyteckiej we Wrocławiu - z warsztatu bibliotekarza}

Abstrakt: Tekst zawiera omówienie kilku wybranych grup druków muzycznych pochodzących z kolekcji Oddziału Zbiorów Muzycznych Biblioteki Uniwersyteckiej we Wrocławiu. Przedmiotem badań są dziewiętnasto- i dwudziestowieczne publikacje, na których umieszczono graficzne przedstawienia ciekawych miejsc z Wrocławia oraz Dolnego Śląska, a także druki zawierające fotografie lub portrety osób ówcześnie związanych z muzyką. Podstawowy cel, który przyświeca rozważaniom, to zbadanie, czy ze względu na swoją szatę graficzną druki muzyczne mogą być rozpatrywane współcześnie jako dokumenty historyczne oraz jak wielką wartość w tym zakresie mają. Warto zwrócić uwagę nie tylko na same obiekty i miejsca przedstawione na drukach, lecz także na sposób wykonania grafik i ich rolę w druku muzycznym, a także odpowiedzieć na pytanie, dlaczego zostały wydane w zestawieniu z konkretnymi utworami muzycznymi oraz na czym dziś polega ich wyjątkowość.

Słowa-klucze: druki muzyczne, XIX-XX wiek, Dolny Śląsk, muzyka, Oddział Zbiorów Muzycznych Biblioteki Uniwersyteckiej we Wrocławiu, Biblioteka Uniwersytecka we Wrocławiu, BUWr, okładki, grafika, dawna fotografia, życie muzyczne w XIX i XX wieku

Muzykalia z Oddziału Zbiorów Muzycznych Biblioteki Uniwersyteckiej we Wrocławiu to niezwykle ciekawa kolekcja. Wraz z unikatowymi starymi drukami i rękopisami muzycznymi przechowywane są tutaj także dziewiętnasto- i dwudziestowieczne druki nutowe, które tworzą najliczniejszą grupę zbiorów. Oprócz powojennej polskiej produkcji wydawniczej gromadzonej na zasadach egzemplarza obowiązkowego i z innych źródeł zbiór zawiera wiele cennych unikatów, między innymi pierwodruki z XIX i początku XX wieku. Te tak zwane druki nutowe nowe, czyli wydane po roku 1800, to około 30 tys. woluminów. Jako wieloletni 
pracownik Oddziału Zbiorów Muzycznych Biblioteki Uniwersyteckiej we Wrocławiu mam to szczęście, że podczas złożonego procesu opracowywania mogę podziwiać ich wyjątkowość. Katalogowanie druków muzycznych wymaga od bibliotekarza przede wszystkim dokładnego ich zbadania. Egzemplarze ogląda się niezwykle wnikliwie, zwracając uwagę na wszystkie szczegóły. Odpowiednia wiedza muzyczna i zdobywane latami doświadczenie pozwalają rozpoznać, czy mamy do czynienia z oryginalnym dziełem, czy jego aranżacją, a może aranżacją autorską funkcjonującą już jako osobny utwór? Czy to fragment dzieła, czy część większej formy, a może też jednocześnie cykl wydawniczy albo seria, w której skład wchodziło wiele podobnie wyglądających wydań, różniących się zawartością? Wątpliwości do wyjaśnienia jest zazwyczaj sporo, dlatego podczas pracy należy wspierać się dostępnymi źródłami (w formie drukowanej i online), a także korzystać z katalogów innych bibliotek na świecie. Wiele publikacji dziewiętnasto- i dwudziestowiecznych może także dziś być cennym materiałem do badań dotyczących ówczesnego repertuaru czy popularności utworów najchętniej aranżowanych na różne składy instrumentów. Przekrój wydań pochodzących z jednego czasu pozwala wyobrazić sobie, jak mogły wyglądać ówczesne preferencje muzyczne, które dzieła były łatwo dostępne i chętnie grane w domowym zaciszu, a jakiej muzyki słuchano podczas koncertów. Mimo że już sama warstwa muzyczna dostarcza licznych tematów, które można by zgłębiać z pozycji muzykologa i muzyka instrumentalisty: forma i struktura dzieł, warstwa harmoniczna, melodyczna, tekstowa - w drukach muzycznych zachwyca coś jeszcze. Wiele z nich także pod względem graficznym jest dziś niespotykanym dokumentem swoich czasów.

Wyobraźmy sobie dziewiętnastowieczną oficynę wydawniczą, miejsce, w którym jednocześnie wydawano, reklamowano i sprzedawano druki. Muzykalia leżały na regałach lub wyeksponowane już przy wejściu próbowały przyciągnąć uwagę klienta. Dobrze ukazują to zachowane archiwalne fotografie takich miejsc. Bardziej doświadczeni muzycy być może poszukiwali od razu konkretnych utworów, ale z pewnością byli też i tacy, w których strona graficzna druku muzycznego mogła wzbudzić zainteresowanie zawartością. O tym, że możliwa była prenumerata ukazujących się w dłuższym przedziale czasowym egzemplarzy, świadczą drukowane na odwrocie okładek reklamy, a także zachowane do dziś odręczne notatki prenumeratorów. Liczne ciekawostki dotyczące druków muzycznych, z którymi spotykam się podczas pracy bibliotekarza, sprawiły, że w szczególny sposób zainteresowałam się organizowaną przez Bibliotekę Kulturoznawstwa i Muzykologii konferencją pt. „Obrazki z nut. Druki muzyczne w kulturze XIX i XX wieku". Pojawiła się idealna okazja, aby opowiedzieć o drukach muzycznych od nieco innej strony niż zwykle. Wybierając obiekty, które przedstawiłam w wystąpieniu pt. „Zatrzymane w czasie. Wartość historyczna szaty graficznej druków muzycznych z kolekcji BUWr", z oczywistych względów nie mogłam pozwolić sobie na zaprezentowanie wszystkich. Dokonanie ostatecznego wyboru spośród wartych uwagi cymeliów okazało się zadaniem bardzo trudnym, ograniczyłam zatem ich liczbę do tych najciekawszych. 
Zauważyłam, że druki, które mogą być rozpatrywane w kontekście dokumentu historycznego, dzielą się na kilka grup. Pierwsza związana jest z ówcześnie znanymi postaciami z życia muzycznego: wirtuozami, aktorami, śpiewakami, kompozytorami. Obecność w druku fotografii lub rycin przedstawiających osoby pozwalała skojarzyć dzieło z konkretnym repertuarem wykonawcy bądź twórcy. Zabieg ten był także bardzo dobrą reklamą. Po wielu latach pamięć o osobach ze zdjęć i rycin wyblakła, lecz druki muzyczne są jej świadectwem. Pieśń Karla Kappellera ,Ich hab 'amal a Räuscherl g'habt!" (sygn. 40273 III N)1', wydana w Wiedniu w 1902 roku, pochodząca z repertuaru Fritzi Massary, ówczesnej śpiewaczki i aktorki rewiowej, to przykład takiej publikacji. Informacje biograficzne o znanej na początku XX wieku postaci są dziś dość lakoniczne. Zdjęcie umieszczone przez wydawcę na okładce to unikat (il. 1).

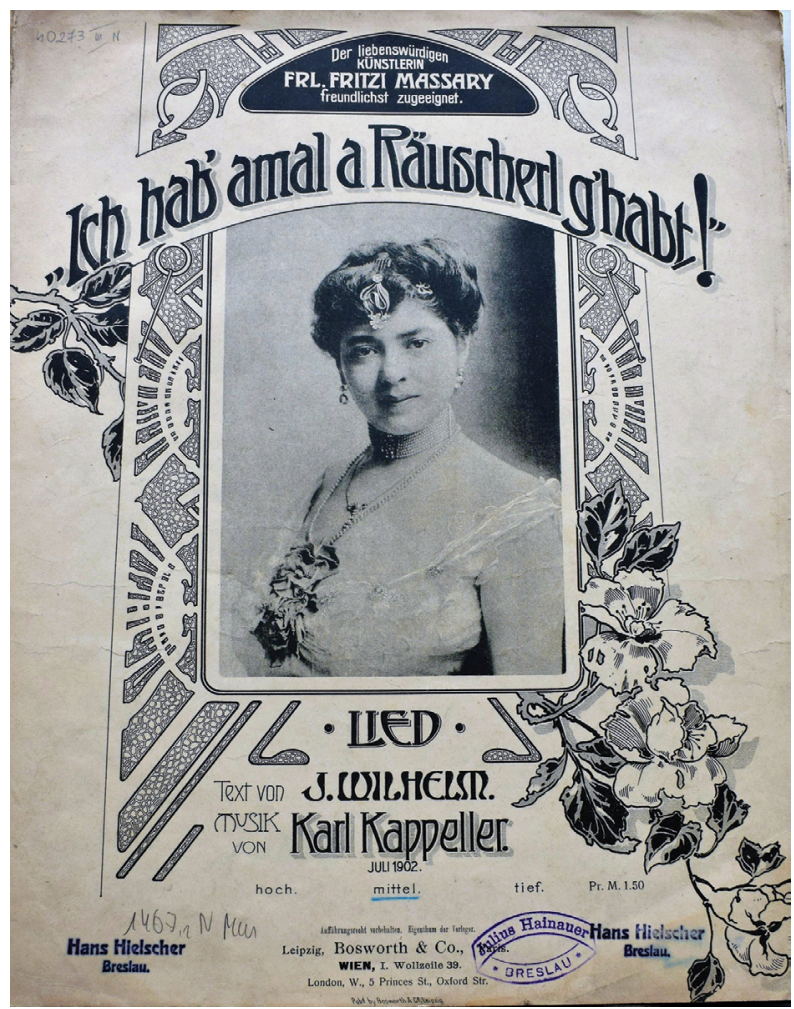

Ilustracja 1. Karl Kappeller, ,,Ich hab' amal a Räuscherl g'habt!”, Bosworth \& Co, Wien [et al.] 1902, okładka

Źródło: zbiory BUWr, OZM, sygn. 40273 III N, fot. J. Konopczak.

1 Wszystkie wymienione w tekście druki muzyczne pochodzą z Oddziału Zbiorów Muzycznych Biblioteki Uniwersyteckiej we Wrocławiu (BUWr, OZM). 
Kolejnym ciekawym przykładem połączenia druku muzycznego z unikatową fotografią jest wydany w Berlinie w 1913 roku Gerhart Fischer: zum Gedächtnis 1894-1913 (sygn. 41001 III N). Publikacja jest zbiorem muzycznej i literackiej twórczości syna znanego ówcześnie niemiecko-węgierskiego wydawcy Samuela Fischera. S. Fischer Verlag założone w 1886 roku w Berlinie zasłynęło z pierwodruków dzieł Henrika Ibsena, którego twórczość zagościła na scenach niemieckich teatrów. Oprócz niepublikowanej nigdzie indziej fotografii druk zawiera także obszerny wstęp biograficzny, przedstawiający postać Gerharta. Dowiedzieć się można z niego między innymi, że chłopiec uczył się muzyki i kompozycji u Paula Juona i był wybitnie uzdolniony w tym zakresie. Razem z rodzicami podróżował po Europie. Zmarł w wieku dziewiętnastu lat $\mathrm{z}$ nieznanych przyczyn. Chcąc uczcić jego pamięć, ojciec wydał okolicznościowy druk muzyczny, który pozwala nam dziś poznać młodego twórcę (il. 2).

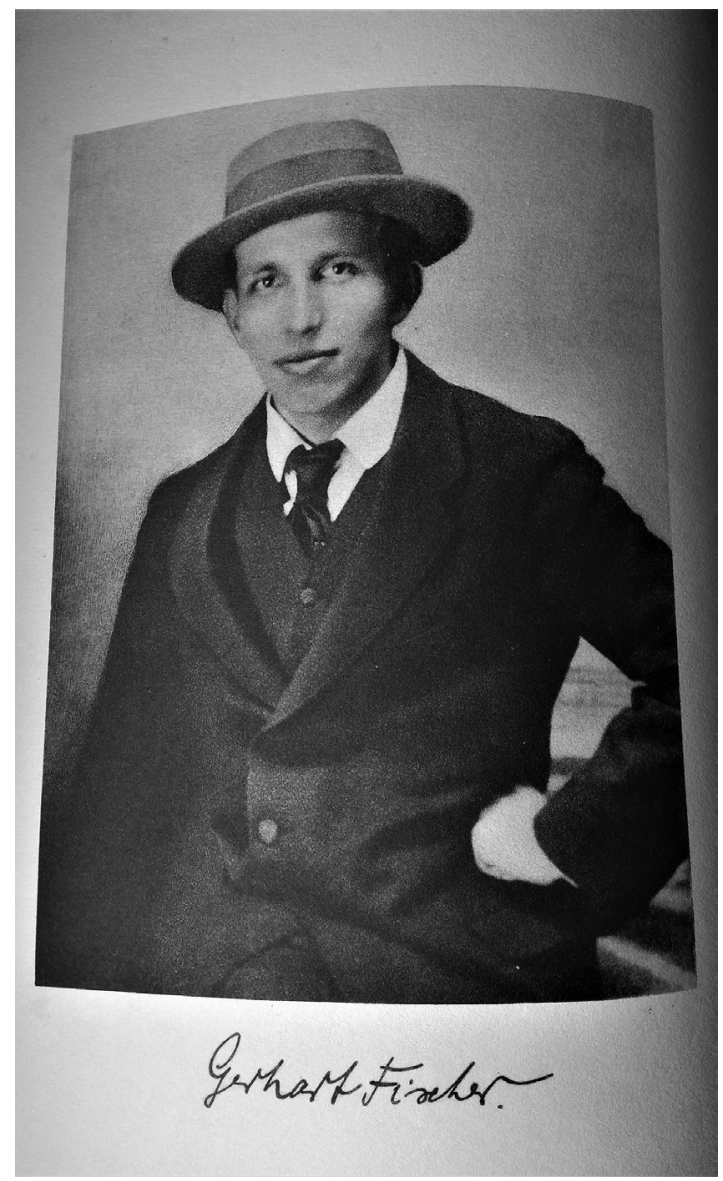

Ilustracja 2. Gerhart Fischer: zum Gedächtnis 1894-1913, Berlin 1913, strona przytytułowa Źródło: zbiory BUWr, OZM, sygn. 41001 III N, fot. J. Konopczak. 
Miejsca

Osobną grupą druków dokumentującą czasy swojego wydania są te, na których widzimy ilustracje konkretnych miejsc. Nabierają szczególnego znaczenia, jeśli porówna się je $\mathrm{z}$ ich dawnym i obecnym wyglądem. Nie zawsze jest to możliwe, gdyż w wypadku niektórych problematyczne jest dziś ustalenie dokładnej lokalizacji. Druk muzyczny zatem znów staje się historycznym dokumentem nie tylko ze względu na zawartość nutową, lecz także na swoją formę graficzną. Oto kilka przykładów:

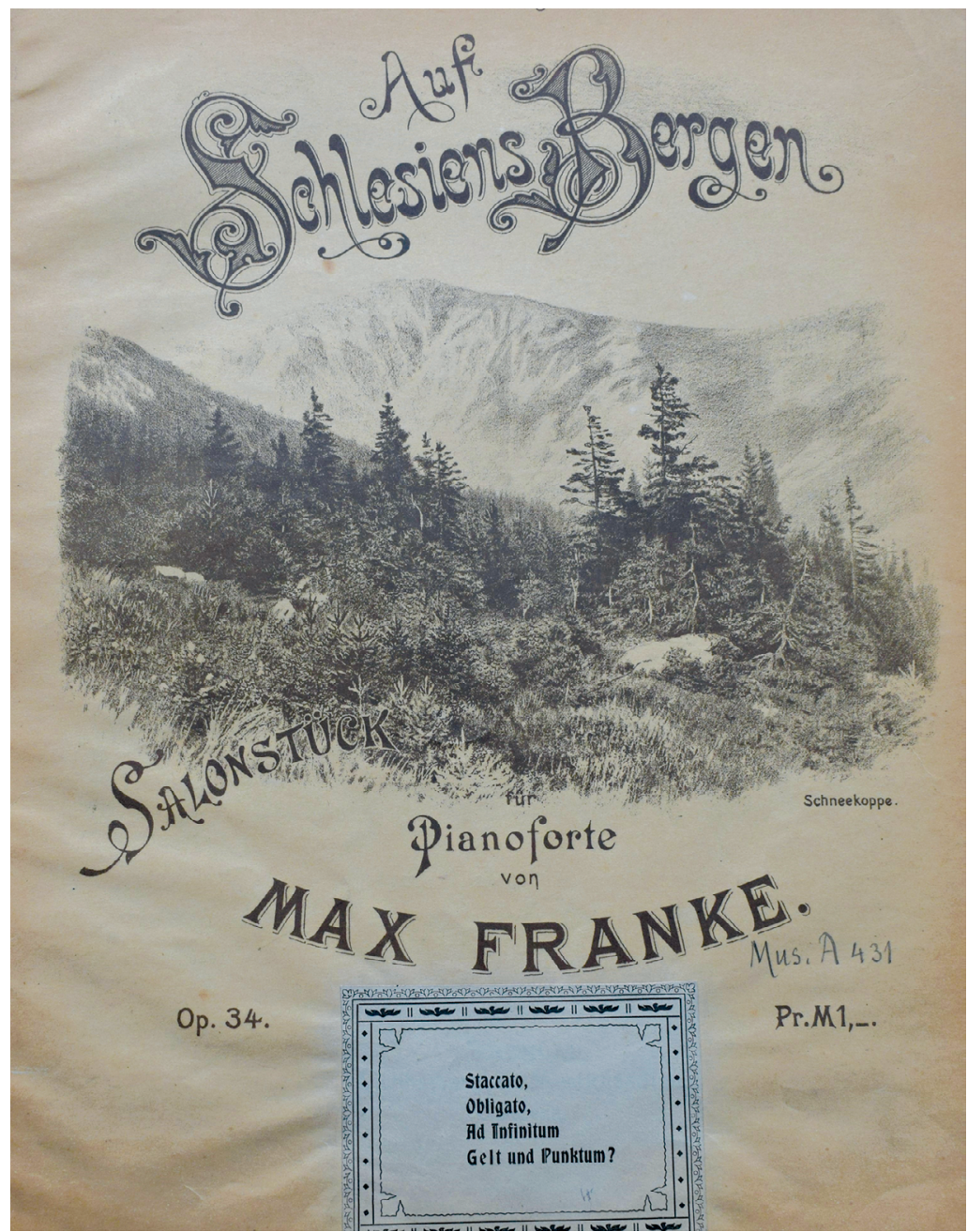

Ilustracja 3. Max Franke, Auf Schlesiens Bergen: Salonstücke für Pianoforte, Verlag der Lichtenberg'schen Musikhandlung (C. Becher), Breslau [ok. 1890], okładka Źródło: zbiory BUWr, OZM, sygn. 37322 III N, fot. J. Konopczak. 
Okładka druku z utworem Maxa Frankego Auf Schlesiens Bergen: Salonstücke für Pianoforte (sygn. 37322 III N), wydanym we Wrocławiu w 1890 roku, przedstawia widok z górskiego szlaku na Śnieżkę (il. 3). Grafika wykonana została z tak dużą dbałością o szczegóły, że mimo podpisu w prawym dolnym rogu ilustracji: „Schneekoppe” bez trudu można zidentyfikować znane miejsce. Sporo czasu zajęło mi odnalezienie punktu, z którego uchwycony został pejzaż. Z pomocą przyszedł turystyczny portal internetowy, który umieścił zdjęcia Śnieżki ze szlaku w okolicy czeskiego Pecu. W drukach muzycznych z kolekcji BUWr można znaleźć wiele śladów szczególnych względów, jakimi Niemcy darzyli Karkonosze. Nie wiadomo, czy to widok Śnieżki zainspirował kompozytora do napisania miniatury na fortepian, czy grafika została dodana w późniejszym czasie do istniejącego już utworu, jednak obecność na okładce druku grafiki rozpoznawalnego wówczas miejsca mogła przyczynić się do zwiększenia zainteresowania muzyką.

Pałac Marianny Orańskiej w Kamieńcu Ząbkowickim (Schloss Camenz) także znalazł się na okładce publikacji. Lob des Schlesierlandes: Lied für eine Singstimme mit Pianofortebegleitung skomponowana przez Franza Gerbera, wydana w 1900 roku (sygn. 37534 III N) została zilustrowana jedną z kolorowych grafik przedstawiającą widok na pałac od strony stawu. Bryła obiektu pozostała niemal niezmieniona do czasów współczesnych. Znów zyskujemy jednak cenny dowód na to, że na początku XX wieku miejsce to cieszyło się znaczną popularnością i było wizytówką Dolnego Śląska (il. 4).

Oprócz grafiki z pałacem na okładce widnieje także inne kojarzone z regionem miejsce, a mianowicie nieistniejąca już kamienna wieża na Śnieżniku (Kaiser Wilhelm Turm). Na temat obiektu i jego historii można odnaleźć dziś sporo informacji. Cennym ich źródłem jest portal internetowy Polska-org.pl i dostępne tam archiwalne fotografie. Pozwoliło to na porównanie wyglądu wieży z okładki i umiejscowienie go w konkretnym czasie, a tym samym umożliwiło dokładniejsze zadatowanie druku. Ustalenie daty wydania poszczególnych egzemplarzy to w pracy bibliotekarza nie lada wyzwanie. Obecność dat na drukach muzycznych należy do rzadkości. Muzyka jako rzecz ulotna i ponadczasowa nie mogła się ,przeterminować”, a zatem podanie daty druku było zbędne. Częstą praktyką stosowaną przez wydawców było przedrukowywanie wcześniejszych wydań $\mathrm{z}$ dodanymi modyfikacjami: nowym numerem wydawniczym, zmienioną okładką i układem strony tytułowej oraz reklamami współtowarzyszącymi publikacji. Zarówno motyw wieży na Śnieżniku, jak i pałacu w Kamieńcu Ząbkowickim wykorzystywane były często również na pocztówkach z początku XX wieku, nie dziwi zatem ich obecność na tak użytkowej formie, jaką był w tym czasie druk muzyczny. W swojej wieloletniej praktyce bibliotekarskiej spotykałam także druki, które były traktowane jak pocztówki. Świadczą o tym widoczne na nich ślady złożenia na cztery części (czasem także zaklejenia brzegów), odręcznie wpisany adres odbiorcy i pozdrowienia z konkretnego miejsca wraz z datą. 


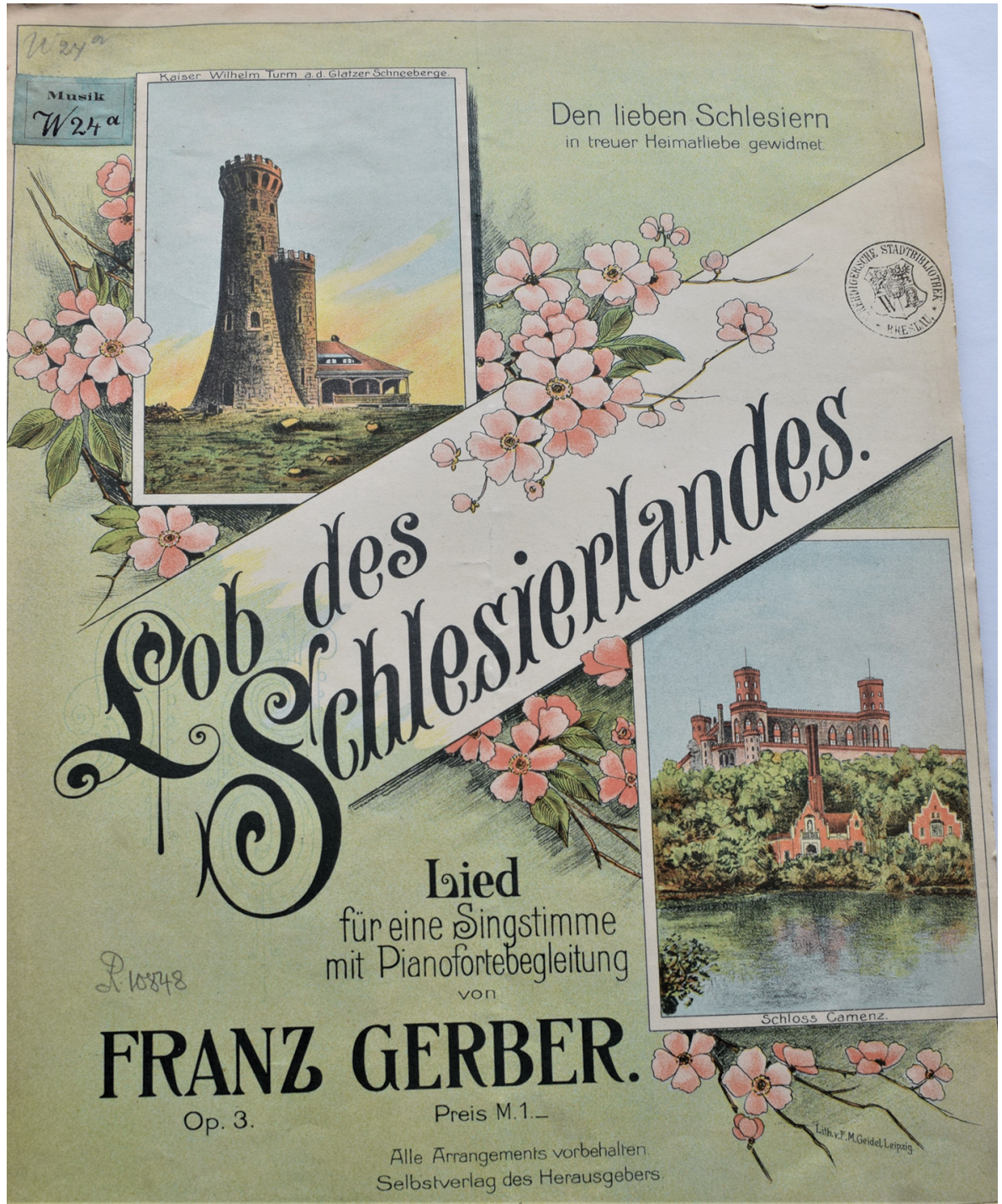

Ilustracja 4. Franz Gerber, Lob des Schlesierlandes: Lied für eine Singstimme mit Pianofortebegleitung, [s. 1, ok. 1900], okładka

Źródło: zbiory BUWr, OZM, sygn. 37534 III N, fot. J. Konopczak.

Jednym z wyjątkowych przykładów udokumentowania historii na druku muzycznym jest okładka Sonate für Violoncell: Opus 41 Ernsta Flügela (sygn. 37120 III N) wydanej we Wrocławiu w 1885 roku. Zrezygnowano tutaj z ozdobnej karty tytułowej opisującej utwór muzyczny i kompozytora na rzecz umieszczenia na pierwszym planie wydawcy: Carla Bechera. Co ciekawe okładka była uniwersalna. 
Była gotowym szablonem, na którym zmieniano tylko dane, a jednocześnie pełniła funkcję ulotki reklamowej. Autor i tytuł dzieła wpisywane były odręcznie w specjalnie przeznaczone do tego miejsce. U góry widnieje adres C. Bechera: „Schweidnitzer Stadtgraben 13 | Gegenüber dem Kaiser-Wilhelm_Denkmal”, z którego wynika, że oficyna wydawnicza znajdowała się naprzeciw pomnika cesarza Wilhelma. Najciekawszą częścią okładki bez wątpienia jest grafika. Przedstawia fragment ulicy Świdnickiej, przy której widać wspomniany w opisie pomnik oraz budynek z numerem 13 (il. 5).

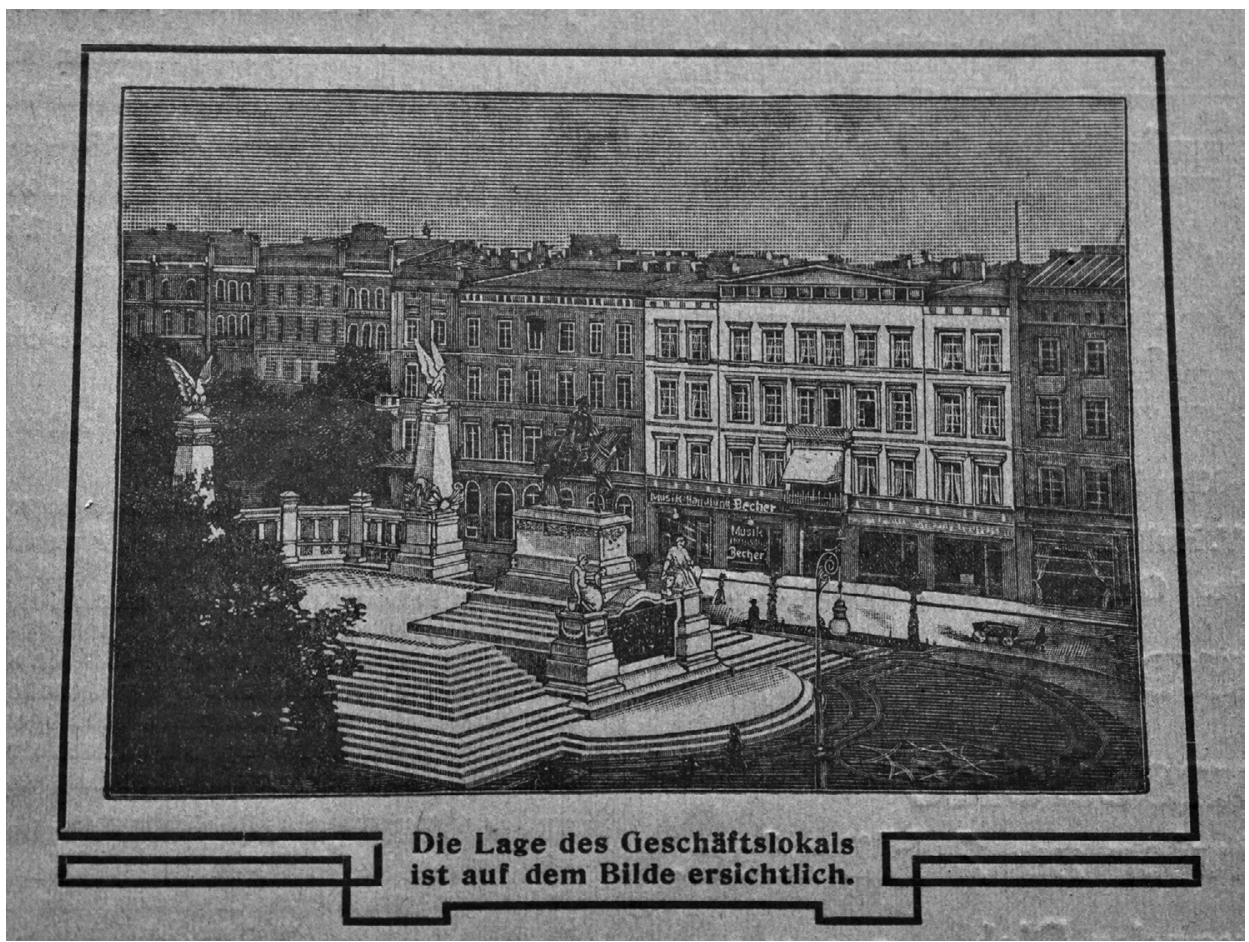

Ilustracja 5. Ernst Flügel, Sonate für Violoncell: Opus 41, Verlag von J. Loebel, Zittau; Otto Junne, Leipzig [ok. 1885], fragment okładki

Źródło: zbiory BUWr, OZM, sygn. 37120 III N, fot. J. Konopczak.

Ilustracja jest dziś cenna z powodu rzadkiego ujęcia perspektywy z tej strony. Na pocztówkach lub zdjęciach z tego okresu najczęściej zobaczyć można pomnik en face oraz fragmenty fosy tuż za nim, na nielicznych jego sylwetka widoczna jest na tle dzisiejszego kościoła Bożego Ciała. Dziś w miejscu dawnych kamienic stoi Warenhaus Wertheim (obecnie Renoma). Widok tej części dawnego Breslau pochodzić musi sprzed roku 1928, kiedy to rozpoczęły się prace budowlane pod nowy obiekt, a zatem znów grafika pomaga w dokładniejszym zadatowaniu druku muzycznego. Widok mimo swoich niewielkich rozmiarów zachwyca kunsztem wykonania. Historyczny wygląd miejsca odwzorowany jest z najdrobniej- 
szymi szczegółami. Dostrzec można takie drobiazgi, jak szyldy nad witrynami sklepowymi, otwarte okna na drugim piętrze kamienicy, ozdobną formę ulicznego oświetlenia czy przechodzącego ulicą człowieka z drewnianym wózkiem.

Warto wskazać także na „Schlesische Musikalische Blumenlese” (sygn. 6418 II N), najstarsze śląskie czasopismo wydawane od roku 1801 we Wrocławiu. Poszczególne zeszyty opatrzone były grafikami bardzo wówczas znanego Friedricha Gottloba Endlera i mogą stanowić dziś doskonałe źródło badań dla historyków. Miejsca przedstawione na nich to widoki pochodzące z Dolnego Śląska, wiele już dziś nie istnieje lub zmieniły się tak dalece, że są trudne do zlokalizowania. Ilustracje zawierają oryginalne podpisy, które mogą dziś ułatwić poszukiwania.

Na okładce pierwszego zeszytu „Schlesische Musikalische Blumenlese” z 1801 roku umieszczona została grafika z ówczesnym widokiem na Fürstenstein — zamek Książ, rzut od strony wąwozu i ruin tak zwanego Starego Książa. Forma obiektu pozostała niemalże niezmieniona do dzisiaj. Wyraźnie widać za to różnicę w kształcie historycznych hełmów wież przy bramie oraz bryle samego zamku (il. 6).

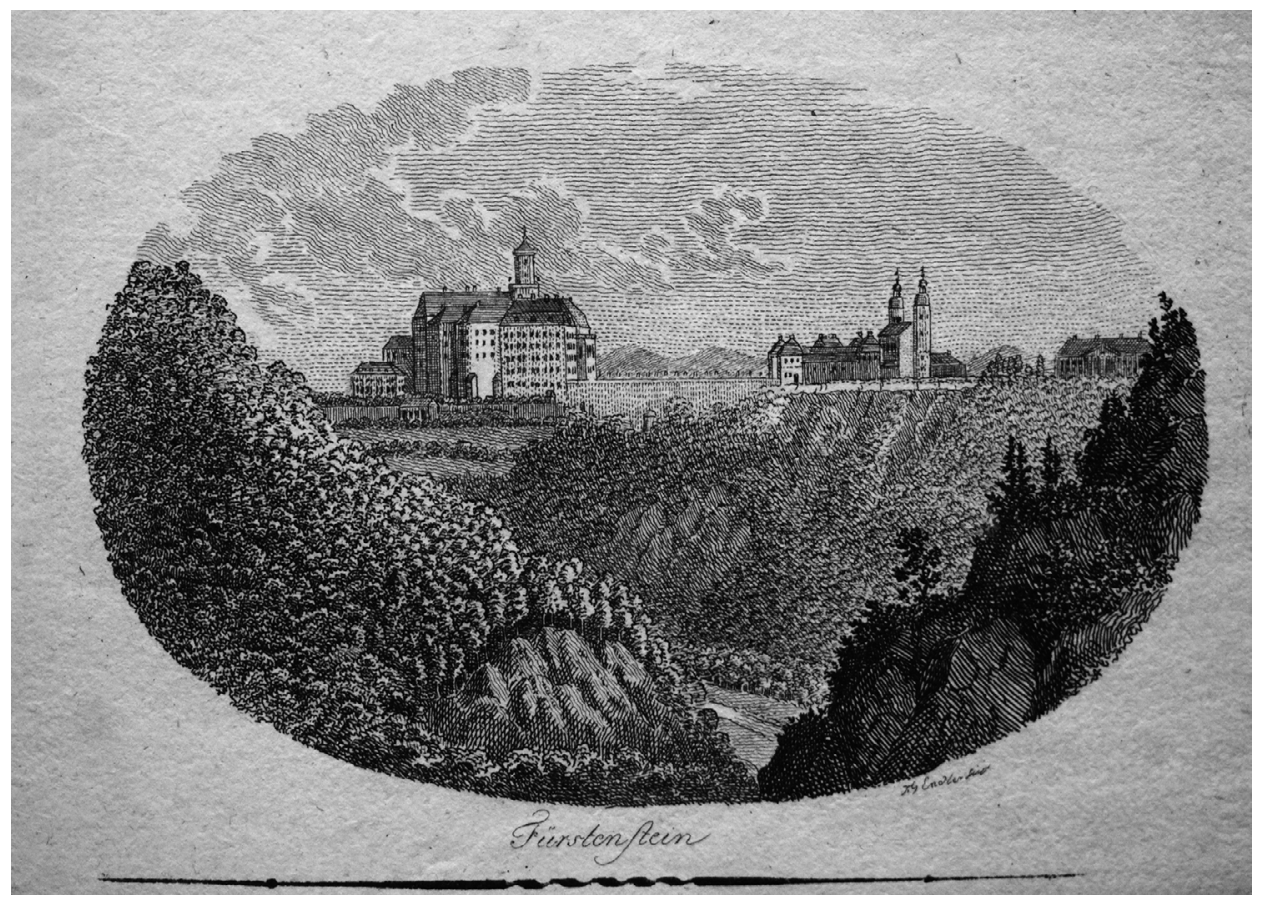

Ilustracja 6. „Schlesische Musikalische Blumenlese” 1801, z. 1, fragment okładki

Źródło: zbiory BUWr, OZM, sygn. 6418 II N, fot. J. Konopczak.

Zeszyt drugi „Schlesische Musikalische Blumenlese” z roku 1803 zawiera widok z Dyherrnfurth - Brzegu Dolnego. Przedstawia fragment ówczesnego portu nad Odrą. Na dalszym planie widoczny pałac rodu von Hoym. Zeszyt trzeci tego 
samego czasopisma pochodzący z 1803 roku opatrzony został grafiką, przedstawiającą „Hütte der Einsamkeit bei Carlsruh”, czyli chatkę „Samotnię” przy wsi Pokój (obecnie woj. opolskie). Od roku 1847 w miejscowości istniało uzdrowisko, założone przez nadwornego lekarza księcia Eugena Friedricha, właściciela wsi. W sanatorium leczono głównie choroby układu nerwowego i choroby reumatyczne. Obiekt działa po dziś dzień, choć obecnie mieści się w nim szpital. Zagadnienie z całą pewnością może być ciekawe dla badaczy historycznej architektury tego miejsca (il. 7).

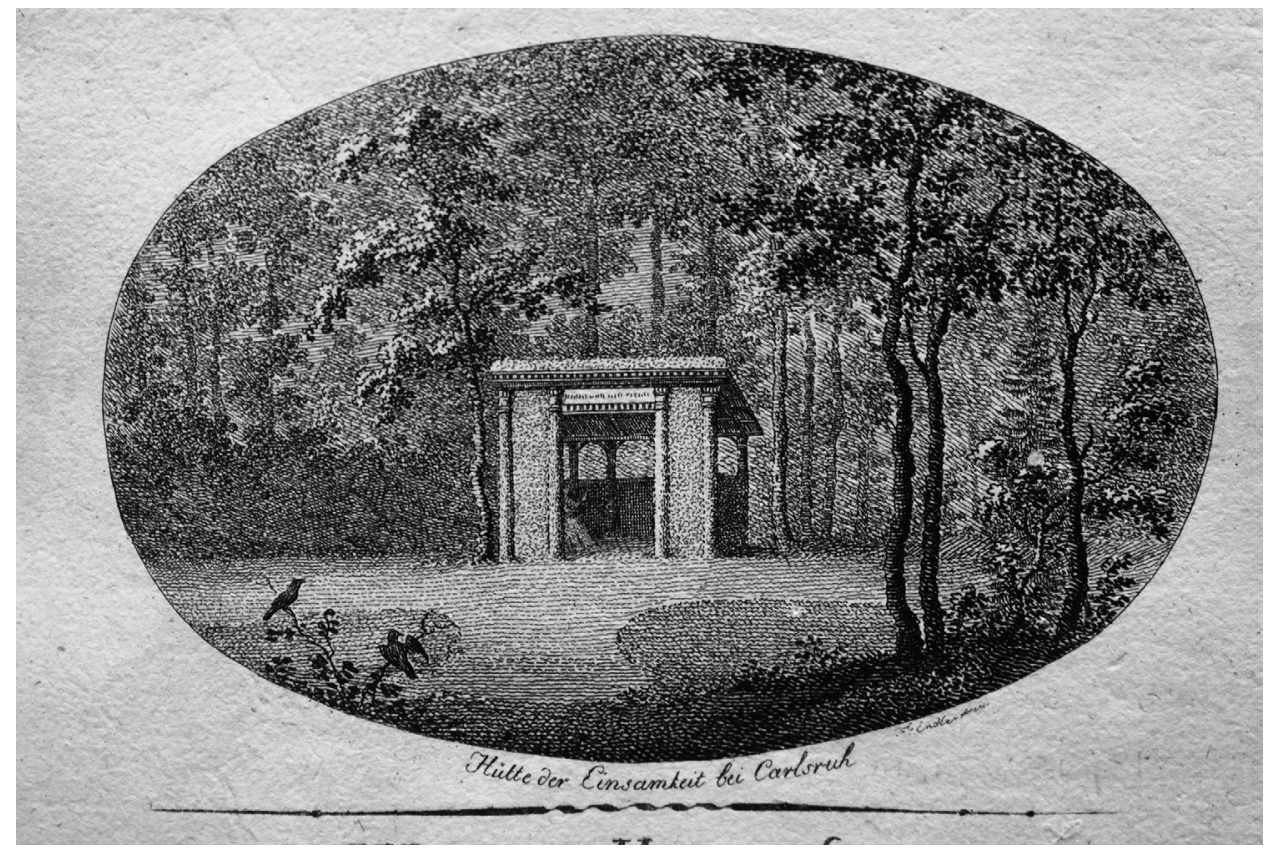

Ilustracja 7. „Schlesische Musikalische Blumenlese” 1803, z. 3, fragment okładki

Źródło: zbiory BUWr, OZM, sygn. 6418 II N, fot. J. Konopczak.

Pamiątkowy obelisk, który znajdował się w Ołdrzychowicach Kłodzkich, przy drodze z Wrocławia do Lądka-Zdroju, możemy zobaczyć na okładce zeszytu czwartego z 1802 roku („Der eiserne Obelisk bei Ullersdorf”). Żeliwny odlew został postawiony jako pamiątka pobytu księcia Fryderyka Wilhelma III i księżnej Luizy w tej okolicy w 1802 roku. Ważył 12,5 tony i był wysoki na niemalże 23 metry. Istniał do 1974 roku, został zlikwidowany podczas prac nad poszerzeniem drogi. Do dziś zachowała się jedynie podstawa, na której obecnie umocowany jest metalowy krzyż. 
Der Kÿnast - zamek Chojnik - jako miejsce również cieszące się wielką popularnością ozdabia okładki dwóch zeszytów „Schlesische Musikalische Blumenlese" - zeszyt pierwszy z 1802 roku i zeszyt czwarty z 1803 roku. Zamek księcia Bolka II będący wizytówką Kotliny Jeleniogórskiej został wzniesiony w XIV wieku, następnie rozbudowany w latach późniejszych. Po dziś dzień jest znaną atrakcją turystyczną. W jednej z baszt obecnie mieści się schronisko.

Grafika podpisana: „Der Prudelberg bei Stohnsdorf”, znajdująca się w roczniku trzecim czasopisma „Schlesische Musikalische Blumenlese”, w zeszycie drugim z 1804 roku to widok góry Witoszy z okolic dzisiejszego Staniszowa. Trasa spacerowa pozwalająca zwiedzić dziś to cieszące się w XIX wieku popularnością miejsce zaczyna się pod kościołem w Staniszowie i jest oznaczona żółtym szlakiem. Do czasów współczesnych zachowały się fragmenty kamiennych schodów, sztucznie ułożone skały tworzące pustelnię i pozostałości wieży Bismarcka na szczycie wzniesienia. Choć góra wygląda dziś niepozornie, kryje ślady dawnych romantycznych spacerów mieszkańców okolicznych pałaców.

Bardzo ciekawy przykład miejsca, które możemy znaleźć na okładce „Schlesische Musikalische Blumenlese" znajduje się także w zeszycie drugim z 1802 roku. Grafika opisana jako „Die Schweizerei im Fürstengrunde” przedstawia działające w XIX wieku schronisko w okolicach Ramiszowa. Dokładna lokalizacja niezachowanego do naszych czasów obiektu pozostaje dziś nieustalona. Ślad, jaki po nim pozostał na okładce muzycznego czasopisma, to niezbity dowód na istnienie tego miejsca, co z kolei zachęca do wnikliwszego zbadania tego tematu.

\section{Druki okazjonalne}

Bardzo ciekawą grupę publikacji tworzą druki okazjonalne. Na większe zainteresowanie zasługuje pochodzący z 1881 roku Zauber Klänge: Walzer für Pianoforte (sygn. 36084 III N), który zawiera utwór Carla Sackura. Był on skomponowany i wykonany z okazji wystawy „Schlesische Gewerbe- und Industrie-Ausstellung" (Śląskiej Wystawy Rzemiosła i Przemysłu) odbywającej się we Wrocławiu, zlokalizowanej przy Rossplatz (późniejszym Benderplatz), a dzisiejszym placu Staszica. Na bogato zdobionej okładce widać rzut na halę wystawową, największy obiekt w zbudowanym na potrzeby ekspozycji miasteczku zaprojektowanym przez architektów Heinricha Brosta i Karla Grossera. Główny pawilon widoczny na okładce druku muzycznego zaprojektował, wzorując się na obiekcie z wystawy w Düsseldorfie, Karl Schmidt (il. 8). 


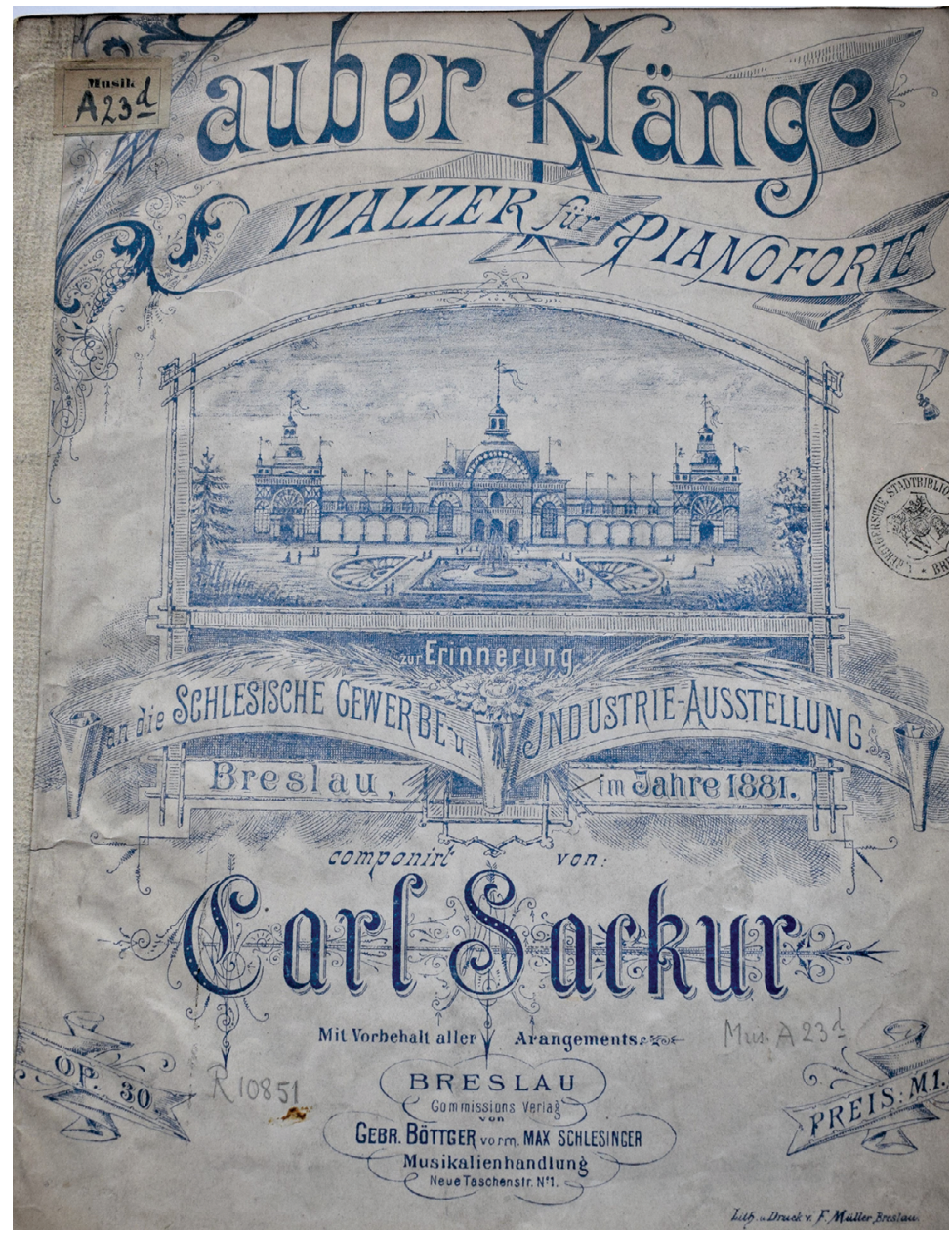

Ilustracja 8. Carl Sackur, Zauber Klänge: Walzer für Pianoforte, Commissions Verlag von Gebr. Böttger vorm. Max Schlesinger Musikalienhandlung, Breslau [1881], okładka

Źródło: zbiory BUWr, OZM, sygn. 36084 III N, fot. J. Konopczak.

Plan aranżacji całej przestrzeni wystawowej można zobaczyć w publikacji pt. Dziewiętnastowieczne wystawy rzemiosła i przemystu Marii Zwierz ${ }^{2}$. Katalog der Gewerbe- und Industrie-Ausstellung dostępny jest w „Schlesische Zeitung” z 27 listopada 1880 roku. Druk muzyczny jest też jedną z form udokumentowania cieszącej się wówczas dużą popularnością wystawy. Jego wyjątkowa wartość to nie tylko grafika $\mathrm{z}$ fragmentem okazjonalnej zabudowy, lecz także niepowtarzalna muzyczna zawartość będącą odzwierciedleniem panującego wówczas uroczystego nastroju.

2 M. Zwierz, Dziewiętnastowieczne wystawy rzemiosta i przemystu we Wrockawiu, [w:] Hans Poelzig we Wrocławiu. Architektura i sztuka 1900-1916, red. J. Ilkosz, B. Stortkuhl, Wrocław 2000, s. 307-324. 
Przytoczone w zaprezentowanym tekście przykłady pozwalają spojrzeć na dziewiętnasto- i dwudziestowieczne druki muzyczne z innej perspektywy, zwrócić uwagę nie tylko na ich nutową zawartość, ale przede wszystkim na formę i szatę graficzną. Potwierdzają, że muzykalia mogą tworzyć wyjątkowe źródło historycznych informacji. W niektórych z nich warstwa muzyczna w nierozerwalny sposób splata się z formą egzemplarza, jak na przykład w utworach okolicznościowych, w których współgrają z sobą muzyka i graficzne udokumentowanie okoliczności wydarzenia. Unikatowe elementy zawarte w drukowanym utworze, jak na przykład fotografie czy ryciny przedstawiające nieistniejące dziś miejsca, mogą stać się dla nas sposobem na przeniesienie się w czasie. Wyjątkowość dawnych muzycznych publikacji wciąż zachwyca i czeka na odkrywanie. Z całą pewnością są one niezwykle cennym materiałem do badań naukowych ${ }^{3}$.

\section{Stopped in time. Historical value of the graphic design of the 19th and 20th century music prints from the collection of the University Library in Wrocław — from the librarian's workshop}

\section{Abstract}

The text contains an overview of a few selected groups of music prints from the collection of the Music Collection Department of the University Library in Wrocław. The subject of research are nineteenth and twentieth century publications with graphic representations of some places from Wrocław and Lower Silesia, as well as prints containing photographs or portraits of people associated with music at that time. The aim is to investigate whether music prints can be historical documents today and how valuable they are. It is also worth paying attention to the way the graphics are made and the role they play in printing. We will also try to find an answer to the question of what is their uniqueness and why they were published in this way.

Keywords: Music prints, 19th-20th century, Lower Silesia, music, Music Collection Department of the University Library in Wrocław, University Library in Wrocław, BUWr, covers, graphics, old photography, musical life in the 19th and 20th centuries

${ }^{3}$ Dziękuję pomysłodawcom i organizatorom konferencji pt. „Obrazki z nut. Druki muzyczne w kulturze XIX i XX wieku” za możliwość podzielenia się spostrzeżeniami z szerszym gronem słuchaczy. 


\section{Bibliografia}

Zwierz M., Dziewiętnastowieczne wystawy rzemiosła i przemystu we Wroctawiu, [w:] Hans Poelzig we Wrocławiu. Architektura i sztuka 1900-1916, red. J. Ilkosz, B. Stortkuhl, Wrocław 2000.

Joanna Konopczak - muzyk instrumentalista, absolwentka wrocławskiej muzykologii na Uniwersytecie Wrocławskim, wieloletni bibliotekarz w Oddziale Zbiorów Muzycznych Biblioteki Uniwersyteckiej we Wrocławiu. Specjalizuje się w badaniach nad muzyką dawną i muzyczną historią Dolnego Śląska.

joanna.konopczak@uwr.edu.pl 